\title{
Anticorpos anti-Neospora spp. em amostras sorológicas de potros pré-colostrais pela técnica de imunofluorescência indireta
}

\author{
Antibodies anti-Neospora spp. in sample sera of presuckle foals by indirect fluorescent antibody test
}

\author{
Felipe Lamberti Pivoto ${ }^{I^{*}}$ Ana Maria Antonello ${ }^{\mathrm{I}}$ Giovana Camillo ${ }^{\mathrm{I}}$ Patricia Braunig \\ Luis Antonio Sangioni ${ }^{I}$ Endrigo Pompermayer ${ }^{I I}$ Fernanda Silveira Flores Vogel ${ }^{\mathrm{I}}$
}

\section{- NOTA -}

RESUMO

Buscou-se detectar a frequência de anticorpos antiNeospora spp. em amostras de potros pré-colostrais, bem como estabelecer a melhor diluição do soro sanguíneo para ser utilizado na imunofluorescência indireta. Foram analisadas 203 amostras sorológicas de potros pré-colostrais, pela reação de imunofluorescência indireta em diferentes titulações. As titulações 16 e 50 apresentaram 25,1\% e 9,9\% de potros précolostrais positivos, respectivamente. Dessa forma, em amostras de soro de animais desprovidos de colostro, pode-se considerar a titulação 16 mais apropriada para detectar a ocorrência de infecção pelo protozoário e assim da transmissão transplacentária pelo Neospora spp. em equinos.

Palavras-chave: diagnóstico, equino, imunofluorescência indireta, Neospora spp., transmissão transplacentária.

\section{ABSTRACT}

The objective of this study was to detect the frequency of antibodies against Neospora spp. in samples of presuckle foal, as weel as determine the best dilution of serum to be used in indirect fluorescent antibody test. We analyzed serum samples from 203 presuckle foals, by indirect fluorescent antibody test in different titrations. The titrations of 16 and 50 showed $25.1 \%$ and $9.9 \%$ of presuckle foals positive, respectively. Thus, in serum samples from presuckle foals the titration 16 can be considered more appropriate to detect the occurrence of infection by the protozoan and therefore the transplacental transmission of Neospora spp. in horses.

Key words: diagnosis, horse, indirect fluorescent antibody test, Neospora spp., transplacental transmission.
Em equinos, a ocorrência da infecção por Neospora spp. foi descrita na América (HOANE et al., 2006; LOCATELLI-DITRICH et al., 2006), Ásia (GUPTA et al., 2002; KLIGLER et al., 2007) e Europa (PITEL et al., 2003; CIARAMELLA et al., 2004; KILBAS et al., 2008; BARTOVÁ et al., 2010). Esse parasito está relacionado a doenças reprodutivas, como aborto e mortalidade neonatal (VERONESI et al, 2008); e principalmente a casos de mieloencefalite protozoária equina (MEP) (VARDELEON et al., 2001; PACKHAM et al., 2002; PITEL et al., 2003; FINNO et al., 2007). O protozoário N. huguesi é o agente etiológico da infecção, sendo ainda incerto se o $N$. caninum também está relacionado à neosporose nesses hospedeiros (DUBEY \& SHARES, 2011).

A infecção pelo $N$. caninum pode ocorrer tanto pela via horizontal, pela ingestão de oocistos excretados pelo hospedeiro definitivo, como pela via vertical, transplacentária (DUBEY, 1999). Porém, em equinos, apesar da suspeita da infecção transplacentária ocorrer (DUBEY \& PORTIFIELD, 1990; TOSCAN et al., 2010), somente recentemente foi comprovada essa via de transmissão pelo $N$. hughesi (PUSTERLA et al., 2011).

A placenta dos equinos é classificada como difusa epiteliocorial microcotiledonária, a qual não possibilita a transferência de imunoglobulinas da égua para seu feto (LeBLANC, 1990; ABD ELNAEIM et al.,

\footnotetext{
'Laboratório de Doenças Parasitárias (LADOPAR), Departamento de Medicina Veterinária Preventiva (DMVP), Centro de Ciências Rurais (CCR), Universidade Federal de Santa Maria (UFSM), Prédio 44, Av. Roraima, 1000, 97105-000, Camobi. Santa Maria, RS, Brasil. E-mail: felipe.pivoto@gmail.com. *Autor para correspondência.

"Equine Hospital, Qatar Racing \& Equestrian Club, Doha, Qatar.
} 
2006). Também o feto equino é capaz de formar uma resposta imune humoral se exposto a um antígeno após 180 dias de gestação (COOK et al., 2001). Portanto, os potros soropositivos em coletas antes da ingestão do colostro foram desafiados pelo Neospora spp. ainda na vida intrauterina, pela forma transplacentária.

Assim, o presente trabalho visa a detectar a frequência de ocorrência de anticorpos em amostras de potros desprovidos de colostro, bem como estabelecer a melhor diluição do soro sanguíneo para ser utilizado na imunofluorescência indireta (IFI). Paralelamente, espera-se reafirmar a ocorrência de infecção transplacentária em equinos pelo referido protozoário. Para tanto, foram coletadas por punção de veia jugular amostras de sangue de 203 neonatos antes da ingestão do colostro, em dois haras localizados no município de Bagé (3119' S e 5406’ W, altitude $212 \mathrm{~m}$ ) na região sudoeste do Rio Grande do Sul, Brasil. Após a obtenção, o sangue total foi centrifugado $250 \mathrm{~g}$ por 10 minutos para separação e então recolhimento do soro, o qual foi estocado a $-20^{\circ} \mathrm{C}$ até ser testado.

A pesquisa de imunoglobulinas da classe $\mathrm{G}$ (IgG) anti-Neospora spp. foi realizada pela técnica de imunofluorescência indireta (IFI), segundo CONRAD et al. (1993). Para tal, foram usados como antígenos primários, taquizoítas de $\boldsymbol{N}$. caninum da cepa NC-1 cultivados em células da linhagem VERO. O anticorpo anti-IgG equina, conjugado à fluoresceína foi usado como anticorpo secundário na reação (LOCATELLIDITTRICH et al., 2006). Amostras de soro sabidamente positivas e negativas quanto à presença de anticorpos anti-Neospora spp. foram utilizadas como controle positivo e negativo, respectivamente. A amostra era considerada positiva quando a fluorescência ocorria em toda a superfície dos taquizoítas de $N$. caninum e negativa quando a fluorescência era apical ou ausente (PARÉ et al., 1995). As amostras de soro de potros desprovidos de colostro foram testadas quanto a presença de anticorpos em duas diluições diferentes: 1:16 e 1:50. As amostras positivas foram testadas até a máxima diluição em que foram detectados anticorpos contra o protozoário.

Foram percebidas diferenças na detecção de anticorpos contra o protozoário quando utilizadas as duas diluições do soro (1:16 e 1:50). Sendo que das 203 amostras de potros pré-colostrais, 25,1\% (51/203) foram positivas com título de 16 e, na diluição de 1:50, a detecção de amostras soropositivas foi de 9,9\% (20/ 203). Esse percentual de amostras soropositivas na diluição de 1:50 foi reduzido para 4,4\% (09/203) quando testadas na diluição de $1: 100,2,9 \%(06 / 203)$ na de $1: 200$ e 1,4\% (03/203) na de 1:400. Em nenhuma amostra foram detectados anticorpos na diluição de 1:800.
Estes resultados demonstram que, para detecção de anticorpos anti-Neospora spp. em amostras de soro de equinos pré-colostrais, a melhor diluição do soro a ser testada é de 1:16, uma vez que apresenta maior sensibilidade. Assim, essa diluição possibilita que potros desafiados pelo Neospora spp., mas com baixa concentração de IgG anti-Neospora spp., sejam detectados, reduzindo a frequência de falsonegativos.

A redução da diluição na IFI torna-se mais necessária quando estamos analisando amostras de soro equino desprovidos de colostro, principalmente para estabelecer a ocorrência ou não de infecção transplacentária, uma vez que amostras sorológicas de potros pré-colostrais apresentam concentrações reduzidas de IgG (LANG et al., 2007). Esses anticorpos presentes no soro dos neonatos são sintetizados pelo feto equino ainda na gestação e os níveis endógenos vagarosamente aumentam, sendo detectadas pequenas quantidades de IgM (8-20 $\left.\mathrm{mg} \mathrm{dl}^{-1}\right)$ e traços de IgG (<15 mg dl ${ }^{-1}$ ) (LeBLANC, 1990).

Resultados de redução gradativa de equinos soropositivos para diferentes titulações foram relatados por VARDELEON et al. (2001), quando analisaram a prevalência de $\boldsymbol{N}$. huguesi e Sarcocystis neurona em diferentes localidades geográficas, e por KLIGLER et al. (2007), que compararam éguas saudáveis, éguas com problemas reprodutivos e equinos com sinais de problemas neurológicos, e observaram que das éguas saudáveis 8,1\% (65/800) eram soropositivas para Neospora spp. na titulação 50 e, quando essas mesmas amostras eram diluídas na concentração de 1:100, 1:200 e 1:400, a soroprevalência reduzia para $1,3 \%(10 / 800), 1,1 \%(09 / 800)$ e $0,8 \%$ (06/ 800), respectivamente.

A titulação 16 apresentou maior frequência de detecção de anticorpos (25,1\%), em relação às demais titulações. No entanto, o estudo visando a investigar a presença de anticorpos anti-Neospora spp. em potros pré-colostrais, realizado por LOCATELLI-DITTRICH et al. (2006), não obteve esse aumento na detecção de anticorpos quando utilizada a titulação 16. Já PACKHAM et al. (2002) observaram falsos positivos na técnica de imunofluorescência indireta, quando testaram o soro de equinos adultos (entre 5 e 18 anos de idade) em titulação $<40$, o que não reduz a confiabilidade de nossos resultados, pelo fato de estarmos padronizando a titulação para sorologia de potros pré-colostrais que sabidamente têm níveis de IgG reduzidas (LeBLANC, 1990).

Amostras de soro de potros desprovidos de colostro apresentam quantidade de anticorpos reduzidos, como demonstrado por LANG et al. (2007), 
os quais testaram o soro de 17 potros pré-colostrais e encontraram valores de IgG inferiores a $100 \mathrm{mg} \mathrm{dL}^{-1}$, através da técnica de imunodifusão radial simples. A diluição do soro de 1:16 aumenta a possibilita de detecção do desafio endógeno pelo Neospora spp., pois aumenta a sensibilidade de detecção de anticorpos. Quanto ao risco de reação cruzada com outros protozoários, a ocorrência é reduzida, visto que os níveis de anticorpos presentes em soros de potros pré-colostrais soronegativos para Neospora spp. por IFI, na titulação 16 , variaram entre $10 \mathrm{mg} \mathrm{dL}^{-1}$ a $80 \mathrm{mg}$ $\mathrm{dL}^{-1}$ (LOCATELLI-DITTRICH et al., 2006). Adicionalmente, somente são consideradas positivas as amostras com fluorescência em toda a superfície do taquizoíto.

Estudos sobre a epidemiologia da neosporose em equinos não estão totalmente elucidados, e dados sobre a possibilidade de desafio endógeno pelo Neospora spp. são de suma importância para o estabelecimento de medidas profiláticas, buscando reduzir os problemas acarretados por esse protozoário. Este trabalho demonstra a presença de anticorpos anti-Neospora spp. em potros desprovidos de colostro e determina a melhor diluição do soro a ser utilizada. Dessa forma, em amostras de soro de animais desprovidos de colostro, pode-se considerar a titulação 16 mais apropriada para detectar a ocorrência de infecção pelo protozoário e assim a ocorrência da transmissão transplacentária pelo Neospora spp. em equinos.

\section{REFERÊNCIAS}

ABD-ELNAEIM, M.M.M. et al. Structural and haemovascular aspects of placentation in young and aged mares. Placenta, v.27, p.1103-1113, 2006. Disponível em: <http:// w w w. sciencedirect.com/s c i ence/article / pi i/ S0143400405002912>. Acesso em: 31 ago. 2011. doi:10.1016/ j.placenta.2005.11.005.

BÁRTOVÁ, E. et al. Neospora spp. and Toxoplasma gondii antibodies in horses in the Czech Republic. Parasitology Research, v.107, n.4, p.783-785, 2010. Disponível em: <http:/ /dx.doi.org/10.1007/s00436-010-1929-4>. Acesso em: 04 nov. 2011. doi: 10.1007/s00436-010-1929-4.

CIARAMELLA, P. et al. Seroprevalence of Neospora spp. in assymptomatic horses in Italy. Veterinary Parasitology, v.123, p.11-15, 2004. Disponível em: <http:// w w w. s ciencedirect.com/s cience / a r ticle / p i i / S0304401704002390>. Acesso em: 24 ago. 2011. doi:10.1016/ j.vetpar.2004.05.022.

CONRAD, P.A. et al. Detection of serum antibody responses in cattle with natural or experimental Neospora infections. Journal of Veterinary Diagnostic Investigation, v.5, p.572578, 1993. Disponível em: <http://vdi.sagepub.com/content/ 5/4/572.full.pdf+html>. Acesso em: 11 jul. 2011. doi:10.1177/ 104063879300500412 .
COOK, A.G. et al. Interpretation of the detection of Sarcocistis neurona antibodies in the serum of young horses. Veterinary Parasitology, v.95, p.187-195, 2001. Disponível em: <http:/ / w w w. sciencedirect.com/s cience/article/pi i/ S0304401700003903>. Acesso em: 04 set. 2011. doi:10.1016/ S0304-4017(00)00390-3.

DUBEY, J.P.; PORTERFIELD, M.L. Neospora caninum (Apicomplexa) in an aborted equine fetus. Journal Parasitology, v.76, p.732-734, 1990.

DUBEY, J.P. Recent advances in Neospora and neosporosis. Veterinary Parasitology, v.84, p.349-367, 1999. Disponível em: <http://dx.doi.org/10.1016/S0304-4017(99)00044-8>. Acesso em: 11 out. 2010. doi:10.1016/S0304-4017(99)00044-8.

DUBEY, J.P.; SCHARES G. Neosporosis in animals - The last five years. Veterinary Parasitology, v.180, p.90-108, 2011. Disponível em: <http://dx.doi.org/10.1016/j.vetpar.2011.05.031>. Acesso em: 04 nov. 2011. doi:10.1016/j.vetpar.2011.05.031.

FINNO, C.J. et al. Equine protozoal myeloencephalitis associated with neosporosis in 3 horses. Journal of Veterinary Internal Medicine, v.21, n.6, p.1405-1408, 2007. Disponível em: <http://dx.doi.org/10.1111/j.1939-1676.2007.tb01966.x>. Acesso em: 04 nov. 2011. doi: 10.1111/j.19391676.2007.tb01966.x.

GUPTA, G.D. et al. Seroprevalence of Neospora, Toxoplasma gondii and Sarcocystis neurona antibodies in horses from Jeju island, South Korea. Veterinary Parasitology, v.106, p.193201, 2002. Disponível em: <http://dx.doi.org/10.1016/S03044017(02)00064-X>. Acesso em: 12 mar. 2011. doi:10.1016/ S0304-4017(02)00064-X.

HOANE, J.S. et al. Prevalence of Sarcocystis neurona and Neospora spp. infection in horses from Brazil based on presence of serum antibodies to parasite surface antigen. Veterinary Parasitology, v.136, n.2, p.155-159, 2006. Disponível em: <http://www.sciencedirect.com/science/article/pii/ S0304401705005200>. Acesso em: 25 maio, 2011. doi:10.1016/j.vetpar.2005.10.023.

KILBAS, Z.G. et al. Seroprevalence of Neospora caninum in racehorse in Ankara, Turkey. Acta Parasitologica, v.53, n.3, p.315-316, 2008. Disponível em: <http://dx.doi.org/10.2478/ s11686-008-0047-2>. Acesso em: 04 nov. 2011. doi: 10.2478/ s11686-008-0047-2.

KLINGER, E.B. et al. Seroprevalence of Neospora spp. among asymptomatic horses, aborted mares and horses demonstrating neurological signs in Israel. Veterinary Parasitology, v.148, p.109-113, 2007. Disponível em: <http://dx.doi.org/10.1016/ j.vetpar.2007.06.002>. Acesso em: 28 jun. 2011. doi:10.1016/ j.vetpar.2007.06.002.

LANG, A. et al. Imunidade passiva em eqüinos: comparação entre a concentração de Ig $\mathrm{G}$ do soro materno, colostro e soro do neonato. Ceres, v.54, n.315, p.405-411, 2007. Disponível em: <http:// www.ceres.ufv.br/CERES/revistas/V54N315P05607.pdf>. Acesso em: 01 set. 2011.

LeBLANC, M.M. Immunologic considerations. In: Equine clinical neonatology. Philadelphia: Lea and Febiger, 1990. p.275-294. 
LOCATELLI-DITTRICH, R. et al. Investigation of Neospora spp. and Toxoplasma gondii antibodies in mares and in precolostral foals from Paraná state, Southern Brazil. Veterinary Parasitology, v.135, n.3-4, p.215-221, 2006. Disponível em: $<$ http//:dx.doi.org/10.1016/j.vetpar.2005.10.010>. Acesso em: 31 ago. 2010. doi:10.1016/j.vetpar.2005.10.010.

PACKHAM, A.E. et al. Qualitative evaluation of selective tests for detection of Neospora hughesi antibodies in serum and cerebrospinal fluid of experimentally infected horses. Journal of Parasitology, v.88, p.1239-1246, 2002. Disponível em: <http://dx.doi.org/10.1645/ 0022-3395(2002)088[1239:QEOSTF]2.0.CO;2>. Acesso em: 24 abr. 2010. doi:10.1645/0022-3395(2002)088[1239:QEOSTF]2.0.CO;2.

PARÉ, J. et al. Interpretation of an indirect fluorescent antibody test for diagnosis of Neospora sp. Infection in cattle. Journal Veterinary Diagnosis Investigation, v.7, p.273-375, 1995. Disponível em: <http://vdi.sagepub.com/content/7/2/ 273.full.pdf>. Acesso em: 15 abr. 2011. doi:10.1177/ 104063879500700222.

PITEL, P.H. et al. Investigation of Neospora sp. antibodies in aborted mares from Normandy, France. Veterinary Parasitology, v.118, p.1-6, 2003. Disponível em: <http:// dx.doi.org/10.1016/j.vetpar.2003.10.007>. Acesso em: 31 ago. 2011. doi:10.1016/j.vetpar.2003.10.007.
PUSTERLA, N. et al. Endogenous transplacental transmission of Neospora hughesi in naturally infected horses. Journal of Parasitology, v.97, n.2, p.281-285, 2011. Disponível em: $<$ http://www.bioone.org/doi/full/10.1645/GE-2657.1>. Acesso em: 01 jul. 2011. doi:10.1645/GE-2657.1.

TOSCAN, G. et al. Neosporose equina: ocorrência de anticorpos anti-Neospora spp. e associação entre status sorológico de éguas e de suas crias. Pesquisa Veterinária Brasileira, v.30, n.8, p. 641-645, 2010. Disponível em: <http://www.scielo.br/pdf/ pvb/v30n8/06.pdf $>$. Acesso em: 01 out. 2011. doi:10.1590/ S0100-736X2010000800006.

VARDELEON, D. et al. Prevalence of Neospora hughesi and Sarcocystis neurona antibodies in horses from various geographical locations. Veterinary Parasitology, v.95, n.24, p.273-282, 2001. Disponível em: <http://dx.doi.org/ 10.1016/S0304-4017(00)00393-9>. Acesso em: 15 maio, 2011. doi:10.1016/S0304-4017(00)00393-9.

VERONESI, F. et al. Neospora spp. infection associated with equine abortion and/or stillbirth rate. Veterinary Research Communications, v.32, supl.1, p.223-226, 2008. Disponível em: <http://dx.doi.org/10.1007/s11259-008-9155-6>. Acesso em: 04 nov. 2011. doi: 10.1007/s11259-008-9155-6. 